\title{
Effect of Paroxetine on the Neuropathic Pain: A Molecular Study
}

\author{
Malek Zarei, Masoumeh Sabetkasaei ${ }^{*}$ and Taraneh Moini-Zanjani \\ Department of Pharmacology, Faculty of Medicine, Shahid Beheshti University of Medical Sciences, Tehran, Iran
}

Received 27 July 2019; accepted 28 October 2019; published online 2 May 2020

\begin{abstract}
Background: Neuropathic pain, due to peripheral nerve damage, has influenced millions of people living all over the world. It has been shown that paroxetine can relieve neuropathic pain. Recently, the role of certain proteins like $B D N F, G A B A A$ receptor, and $K C C 2$ transporter in the occurrence of neuropathic pain has been documented. In the current study, the expression of these proteins affected by paroxetine was evaluated. Methods: Male Wistar rats were allocated into two main groups of pre- and post-injury. Rats in each main group received paroxetine before nerve injury and at day seven after nerve damage till day 14, respectively. The lumbar spinal cord of animals was extracted to assess the expression of target genes and proteins. Results: In the preventive study, paroxetine decreased $B D N F$ and increased $K C C 2$ and GABAA gene and protein expression, while in the post-injury paradigm, it decreased $B D N F$ and increased $K C C 2$ genes and protein expression. In this regard, an increase in the protein expression of GABAA was observed. Conclusion: It seems that paroxetine with a change in the expression of three significant proteins involved in neuropathic pain could attenuate this type of chronic pain. DOI: 10.29252/ibj.24.5.301
\end{abstract}

Keywords: Brain-derived neurotrophic factor, Gamma-aminobutyric acid, Paroxetine

Corresponding Author: Masoumeh Sabetkasaei

Department of Pharmacology, Faculty of Medicine, Shahid Beheshti University of Medical Sciences,Tehran, Iran; Tel.: (+98-21) 22439969;

Fax: (+98-21)22439969; E-mail: fkasaei@yahoo.com

\section{INTRODUCTION}

$\mathrm{N}$ europathic pain occurs by damage to the somatosensory system, including peripheral and central neurons, through some diseases like diabetes mellitus, trauma, and cancer ${ }^{[1]}$. Although the aspects about the management of neuropathic pain have been changed, there are limited data on the pathogenesis of this pain ${ }^{[2,3]}$. In spite of the recent progress in neurosciences and pharmaceutical technology, no effective drug, with a clear mechanism, has been developed to manage the neuropathic pain ${ }^{[4]}$.

Among different mechanisms involved in the neuropathic pain, the GABAergic system is the key player. $G A B A$ receptors located in pre- and postsynaptic terminals of primary afferent neurons are also found in the dorsal horn laminae I-IV ${ }^{[5]}$. Dorsal horn GABAergic interneurons play an important role in decreasing pain $^{[6,7]}$. So far, the relationship between the
GABAergic system and neuropathic pain has not been understood well ${ }^{[8]}$. It has been shown that GABAergic neurons transplanted to subarachnoid space attenuate hyperalgesia produced by nerve damage in rat ${ }^{[9]}$. Moreover, muscimol, as a GABAA receptor agonist decreases hyperalgesia caused by peripheral neurons injury ${ }^{[10]}$. The normal function of the GABAergic system is extremely dependent on cation-chloride cotransporters. The influx and efflux of chloride into and out of neurons are facilitated mostly by NKCC1 and $K C C 2$, respectively ${ }^{[11,12]}$. Both NKCC1 and $K C C 2$ expressed in spinal cord regulate intracellular chloride homeostasis. Various studies have indicated that the altered expression of these transporters can change neuropathic pain behavior ${ }^{[6,7,13,14]}$. On the other hand, the elevated concentration of intracellular chloride diminishes the inhibitory effect of $G A B A$ receptors ${ }^{[8]}$.

New data show that glial cells in spinal cord cause hypersensitivity and continuation of pain in $\mathrm{CNS}^{[15]}$. 
Nerve injury not only increases specific microglia markers expression (Ibal) but also releases some painful mediators such as BDNF, prostaglandin E2, nitric oxide, and tumor necrosis factor- $\alpha$. These factors produce hypersensitivity in CNS through rising the excitability and decreasing the inhibition of DRG neurons ${ }^{[16]}$. Most of these mediators have a significant role in the production of chronic pain ${ }^{[17]}$.

Damage to nerve activates p38MAPK pathway in DRG and microglial cells ${ }^{[18]}$. A recent study has suggested that the activation of the p38MAPK pathway by ATP and purinergic P2X4 receptor in microglia results in the production and release of $B D N F^{[19]}$. Investigations have also displayed that $B D N F$ has a prominent function in neuropathic pain. Thermal hyperalgesia and mechanical allodynia are induced by intrathecal administration of $B D N F^{[20]}$. Other studies have revealed that nerve injury and peripheral inflammation change gene expression and production of $B D N F^{[21,22]}$. BDNF has ability to change the function of $G A B A A$ receptor $^{[23]}$ and also alters $K C C 2$ gene expression, thereby effluxing chloride from the neuron; these changes finally result in chloride efflux through $G A B A A$ and accordingly, depolarization of neurons ${ }^{[24]}$. Based on evidence, alteration in $K C C 2$ expression gives rise to a change in $G A B A A$ behavior from inhibitory to excitatory in some subtypes of injured nerves ${ }^{[6]}$. The GABAA receptor subtypes $\alpha_{2}$ and $\gamma_{2}$ is expressed mostly in the spinal dorsal horn. Although $\gamma_{2}$ subunit gene expression decreases after nerve injury, $\alpha_{2}$ subtype expression has no significant changes ${ }^{[25]}$.

Considering P2X4 receptors role in the release of important mediators involved in neuropathic pain, inhibition of this receptor can be helpful to understand the mechanism of neuropathic pain. Up to now, no selective inhibitor of the $\mathrm{P} 2 \mathrm{X} 4$ receptor has been presented $^{[26]}$. Antidepressant drugs, specifically tricyclic antidepressants have been widely used to manage neuropathic pain. It has been demonstrated that some antidepressants and antiseizure drugs are applied to treat neuropathic pain and inhibit the $\mathrm{P} 2 \mathrm{X} 4$ receptor ${ }^{[27]}$. Among the antidepressants, paroxetine has a significant inhibitory effect on P2X4 receptors ${ }^{[28,29]}$. In the current study, we aimed to find out any possible changes in the expression of some proteins involved in the neuropathic pain (Ibal, BDNF, KCC2, and $G A B A A\left(\gamma_{2}\right)$ affected by paroxetine.

\section{MATERIALS AND METHODS}

\section{Animals}

Rats (male Wistar, 150-200 g) used in the study were housed in an environment with controlled temperature $\left(23 \pm 2{ }^{\circ} \mathrm{C}\right)$. Food and water were available to animals without any limitation. At least one week before surgery, all the rats were permitted to be adapted to the housing facilities.

\section{Surgery and drug preparation}

The left sciatic nerve close to trifurcation was tied loosely (4 ligatures) by chromic gut suture, and thus, a model of neuropathic pain so-called CCI was created. Except for the sham group, the left sciatic nerve was tied in both drug and control groups. After ligation, the wound was closed. All surgical procedures were under sterile condition. Ketamine $(60 \mathrm{mg} / \mathrm{kg})$ and xylazine $(10 \mathrm{mg} / \mathrm{kg}$ ) were administered for the induction of aanesthesia. Paroxetine hydrochloride (Sigma, USA) was dissolved in DMSO 5\%.

\section{Drug administration}

Animals were placed to pre- and post-injury groups. In each group, the rats were divided into CCI vehicletreated (control), sham, and CCI paroxetine-treated groups. CCI- and sham-operated animals received the vehicle. Paroxetine was administered (i.p.) to the drugtreated group before and after surgery. In the preemptive paradigm, $10 \mathrm{mg} / \mathrm{kg}$ of paroxetine was injected to rats one hour prior to surgery and then daily after surgery until day 14 . Animals in the post-injury group received the drug the same dose as the preventive group at day seven post-injury and then daily until day 14 .

\section{Tissue collection for RT-PCR and Western blot analysis}

After euthanizing by $\mathrm{CO}_{2}$ asphyxiation, rats were decapitated immediately on day 14 post surgery. The spinal cord displaced by the normal saline from the vertebral column was frozen in dry ice. For evaluating gene and protein, the lumbar spinal cord segment was isolated from the intact frozen cord.

\section{Gene expression study}

Isothiocyanate-phenol-chloroform protocol was used for the isolation of total RNA, using RNX+ reagent (Cinaclon, Iran), according to the instructions provided by the manufacturer. Based on the manufacturer's protocol, $2 \mu \mathrm{g}$ of total RNA, Oligo(dT) primer (Fermentas, USA), and M-MuLV reverse transcriptase (Fermentas) was used for the synthesis of cDNA. As shown in Table 1, designing of primer sequences (CinnaGen, Iran) was performed as per sequences in the GenBank. The PCR was carried out using the synthesized cDNA, the specific primers, and Taq DNA Polymerase MasterMix. In the beginning, the PCR was run for $10 \mathrm{~min}\left(95{ }^{\circ} \mathrm{C}\right)$, then continued by amplification cycles ( 25 or 26 ), each including 1-min denaturation $\left(95{ }^{\circ} \mathrm{C}\right)$, annealining $\left(45 \quad \mathrm{~s}, \quad 59{ }^{\circ} \mathrm{C}\right)$, and extension $\left(45 \mathrm{~s}, 72{ }^{\circ} \mathrm{C}\right)$ steps. PCR products were 
Table 1. Primer sequences for the PCR amplification of genes of interest

\begin{tabular}{cccc}
$\begin{array}{c}\text { Target } \\
\text { gene }\end{array}$ & $\begin{array}{c}\text { Primer } \\
\text { name }\end{array}$ & Sequence 5' to 3' & $\begin{array}{c}\text { Primer } \\
\text { length (bp) }\end{array}$ \\
\hline \multirow{2}{*}{ Ibal } & F-iba1 & 5' ACAAGCACTTCCTCGATGATC 3' & 21 \\
& R-iba1 & 5' GCAACTCAGAAATAGCTTTCTTG 3' & 23 \\
BDNF & F-bdnf & 5' GCTGCGCCCATGAAAGAAGC 3' & 20 \\
& R-bdnf & 5' GAACCCTCATCGACATGTTTG 3' & 21 \\
$K C C 2$ & F-kcc2 & 5' AGGAGGAGATGGACACCAGCCC 3' & 22 \\
& R-kcc2 & 5' GCGTAGATGGCCAGGCCAGG 3' & 20 \\
$G A B A A / \gamma 2$ & F-gaba-a & 5' AAGATTATGCTTCTAATAAAAC 3' & 22 \\
& R-gaba-a & 5' CACCATATTGCTATTCAATCG 3' & 23 \\
GAPDH & F-gapdh & 5' GTTACCAGGGCTGCCTTCTCTTG 3' & 23 \\
\hline
\end{tabular}

separated on agarose gel (1.5\%; Roche, Germany), stained with SYBR Green staining and visualized under a UV light. The PCR bands intensities, as an indicator of the gene expression levels, were measured by the Laboratory Works software version 4 (UVP, UK).

\section{Western blot analysis}

For protein expression assay, Western blotting was used. Tissue samples were lysed in RIPA buffer (150 $\mathrm{mM}$ of $\mathrm{NaCl}, 1 \% \mathrm{NP}-40,50 \mathrm{mM}$ of Tris $\mathrm{pH} 8.0,1 \%$ SDS, $0.5 \%$ sodium deoxycholate, and $1 \mathrm{mM}$ of EDTA and protease inhibitor cocktail) and centrifuged at $20,000 \times \mathrm{g}$ at $4^{\circ} \mathrm{C}$ for $20 \mathrm{~min}$. After adding the SDS sample buffer to the aliquots of tissue extracts, the samples were placed in a water bath at $100{ }^{\circ} \mathrm{C}$ for 5 min. Proteins were separated on $10 \%$ SDS-PAGE and then transferred to the blot. Blot membranes were incubated with 1:500 dilution of specific primary polyclonal rabbit antibodies against $B D N F, K C C 2$, $G A B A A / \gamma_{2}$, and Ibal and 1:1000 dilution of $G A P D H$ (all from Abcam, USA) in TBS-T for $18 \mathrm{~h}$. Blots were then incubated separately with secondary anti-rabbit (1:500 dilution; Abcam) in TBS-T for $90 \mathrm{~min}$. KCC2, $G A B A A / \gamma_{2}, B D N F$, and Ibal immune-reactive proteins were detected using achemiluminescence kit (Enhanced Chemiluminescence, Amersham Biosciences, UK). The signal intensity of the detected bands was measured by an image analysis system (Image j, version 1.46r).

\section{Statistical analysis}

Statistical analyses were performed by SPSS 18 software using ANOVA, followed by Tukey's post hoc test. Statistical significance was indicated by $p<0.05$.

\section{Ethical statement}

The above-mentioned sampling and treatment protocols were approved by the Research Ethics Committee of Shahid Beheshti University of Medical Sciences, Tehran, Iran (ethical code: SBMU.REC1393. 327).

\section{RESULTS}

\section{Effect of prophylactic administration of paroxetine on the gene expression}

Paroxetine and control groups showed a significant difference in the ibal expression $(p<0.01$ and $p<$ 0.001 , respectively) relative to the sham group Fig. 1). Compared to the control group, paroxetine decreased the expression of BDNF $(p<0.001)$. In comparison to the sham and control groups, the expression of $K C C 2$ decreased and increased significantly in the control $(p$ $<0.05)$ and paroxetine $(p<0.05)$ groups. However, paroxetine decreased the gene expression of $G A B A A / \gamma_{2}$ $(p<0.05)$ compared to the sham group.

\section{Effect of paroxetine on gene expression after nerve injury}

As depicted in Figure 2, a significant rise was seen in the expression of Ibalin the control $(p<0.001)$ and paroxetine $(p<0.01)$ groups compared to the sham group. The paroxetine-treated group showed a significant decline in the expression of $B D N F$ compared to the control $(p<0.05)$ and sham $(p<0.01)$ groups. $K C C 2$ gene expression showed a significant reduction in the control group in comparison to the sham group $p<0.01)$. Compared to the control, the paroxetine group showed a significant rise $\left({ }^{+} p<0.05\right)$ in $K C C 2$ gene expression. Moreover, no significant decrease was observed in the expression of $G A B A A / \gamma_{2}$ in the drug-treated group relative to other groups. 


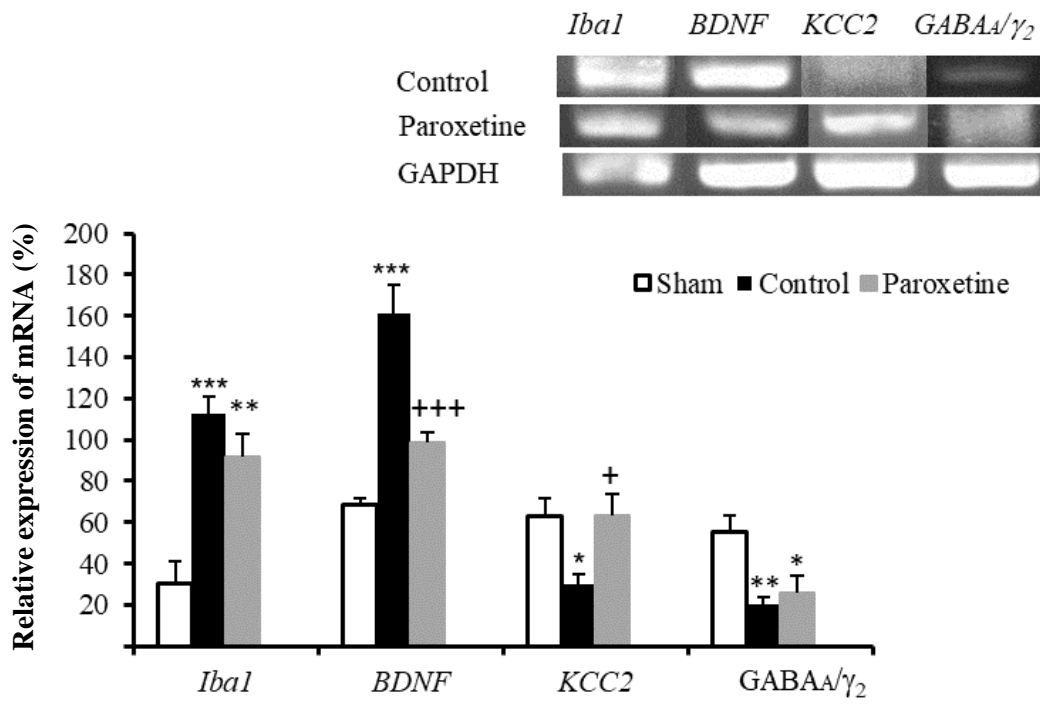

Fig. 1. Effect of pre-injury administration of paroxetine on the gene expression of $I b a 1, B D N F, K C C 2$, and $G A B A A / \gamma_{2}$. GAPDH was used as a loading control. Relative expression of mRNA: band density of genes/GAPDH band density. Data are expressed as means \pm SEM. ${ }^{*} p<0.05,{ }^{* *} p<0.01$, and ${ }^{* * *} p<0.001$ indicate a statistically significant difference compared to the sham group, and ${ }^{+} p<0.05$ and ${ }^{+++} p<0.001$ show significant difference compared to the control group.

\section{Effect of prophylactic injection of paroxetine target proteins}

As it is clear from Figure 3, compared to the sham group, the expression level of the microglia marker (Iba1) rose in the control $(p<0.001)$ and paroxetine $(p$ $<0.01)$ groups. Paroxetine could decrease the BDNF protein level significantly as compared to the sham $\left({ }^{* *} p\right.$ $<0.01)$ and the control $(p<0.001)$ groups. Compared to the control group, $\mathrm{KCC} 2$ showed a significant rise in the paroxetine group $(p<0.05)$. On the other hand, a significant difference in GABAA $/ \gamma_{2}$ levels $(p<0.001)$ was found between paroxetine and control group.

\section{Effect of paroxetine on the expression of target proteins after nerve injury}

There was a significant rise in Iba1 protein level in the control and paroxetine groups as compared to the sham group ( $p<0.001$; Fig. 4). On the other hand, compared to the control group, the expression of BDNF protein decreased significantly in

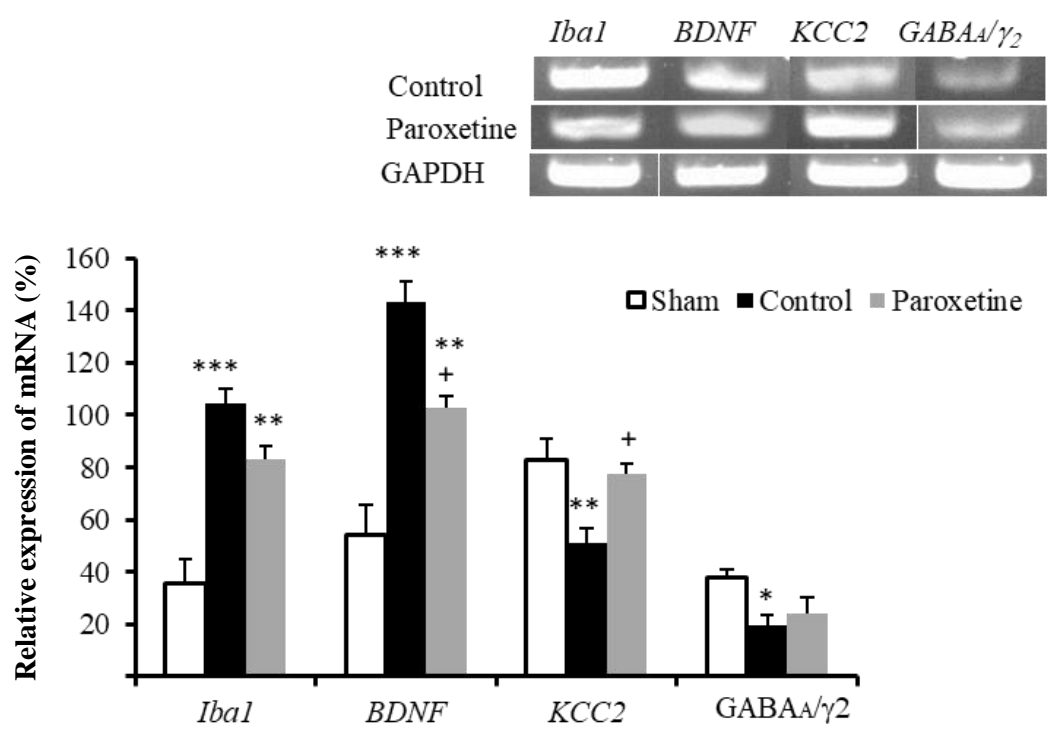

Fig. 2. Effect of paroxetine on the gene expression of $I b a 1, B D N F, K C C 2$, and $G A B A A / \gamma_{2}$ administered after nerve injury. GAPDH was used as a loading control. Relative expression of mRNA: band density of genes/GAPDH band density. Data are expressed as means \pm SEM. ${ }^{*} p<0.05,{ }^{* *} p<0.01$, and ${ }^{* * *} p<0.001$ indicate a statistically significant difference when compared to the sham group, and ${ }^{+} p<0.05$ shows significant difference compared to the control group. 


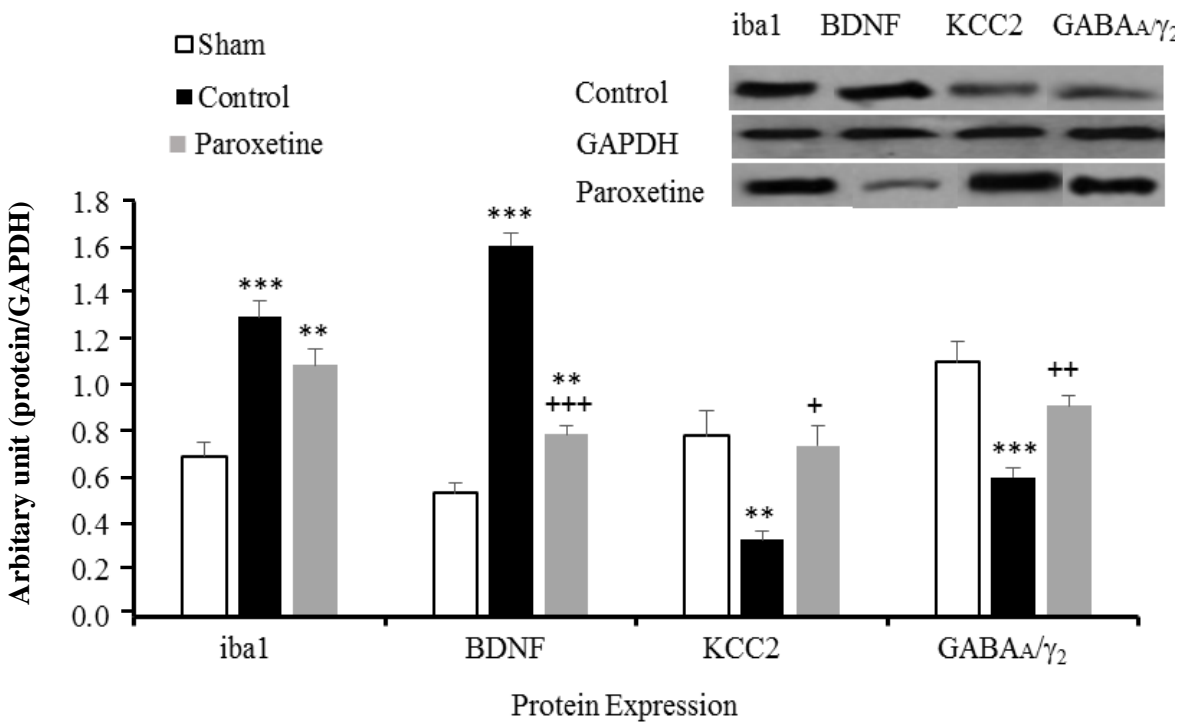

Fig. 3. Effect of prophylactic injection of paroxetine on the protein expression levels of Iba1, BDNF, KCC2, and GABAA $\gamma_{2}$. GAPDH was used as a loading control. Arbitrary unit: proteins optical density/GAPDH optical density. Data are expressed as means \pm SEM. ${ }^{* *} p<0.01$ and ${ }^{* * *} p<0.001$ indicate a statistically significant difference when compared to the sham group, and ${ }^{+} p<0.05,{ }^{++} p<$ 0.001 , and ${ }^{+++} p<0.001$ show significant difference compared to the control group.

the paroxetine-treated group $(p<0.01)$. Paroxetine increased the $\mathrm{KCC} 2$ expression compared to the control group $(p<0.05)$. GABAA $/ \gamma_{2}$ protein levels showed no change in the drug-treated group in comparison with the control group.

\section{DISCUSSION}

In the present study, the effect of paroxetine on the expression of certain important mediators involved in neuropathic pain was investigated. Our data indicated an altered expression of $B D N F$ and $K C C 2$ upon administration of paroxetine. This was also the case for $G A B A A / \gamma_{2}$ proteins when the drug was injected before nerve damage. Microglial cells remain in resting state under physiological conditions and have appendages morphologically. Nerve injuries and lesions activate microglial cells and change their morphology with losing the appendages as well as swelling. After nerve injury, the gene expression level of P2X4 receptor and the Iba1 protein levels increased in microglial cells $^{[30,31]}$. It has been shown that Ibal gene is specifically expressed in microglial cells in the $\mathrm{CNS}^{[32]}$ but not in other cells (neurons, astrocytes, and oligodendrocytes) ${ }^{[33]}$. Studies have evidenced the significant role of Iba1 in the migration and phagocytic activity of microglial cells ${ }^{[34]}$. Moreover, the expression of this protein and mechanical allodynia elevates after SNL in the rat ${ }^{[35]}$. As noted previously, paroxetine has the most effect on the inhibition of the $\mathrm{P} 2 \mathrm{X} 4$ receptor among various antidepressants and antiepileptic drugs used in neuropathic pain. A previous study has indicated that the expression of this receptor enhances in microglia after the nerve injury, and the neuropathic pain symptoms are also observed more frequently afterward. However, there is no change in the expression of this receptor in nerve cells or astrocytes ${ }^{[36]}$. Another report has suggested that the P2X4 ionotropic receptor is expressed only in microglia and its expression increases after neuropathy ${ }^{[37]}$. Consistent with our data, some behavioral and biochemical findings have demonstrated that the activity of $\mathrm{P} 2 \mathrm{X} 4$ receptors expressed in dorsal horn microglia is necessary for the induction of mechanical allodynia ${ }^{[38,39]}$. A number of investigations have revealed that BDNF neurotrophin has a critical role in neuropathic pain and its expression boosts in the spinal cord dorsal horn and $\mathrm{DRG}^{[40,41]}$. The activation of the $\mathrm{P} 2 \mathrm{X} 4$ receptor in microglia is essential for the expression and release of BDNF after peripheral nerve injury, which in turn leads to the increased pain transfer in neurons ${ }^{[19]}$. It has also been suggested that BDNF indirectly facilitates the release of GABA from the spinal cord interneurons ${ }^{[22]}$, and $B D N F$ expression increases in the spinal cord (dorsal horn) 24 hours after SNL, and this elevation continues for several days ${ }^{[40]}$. In the present study, while after CCI, the expression of the $B D N F$ gene enhanced significantly, paroxetine reduced the expression of this neurotrophin both before and after the nerve injury. Our previous surveys demonstrated that the prophylactic injection of paroxetine could diminish neuropathic pain ${ }^{[42]}$. Considering the key role 


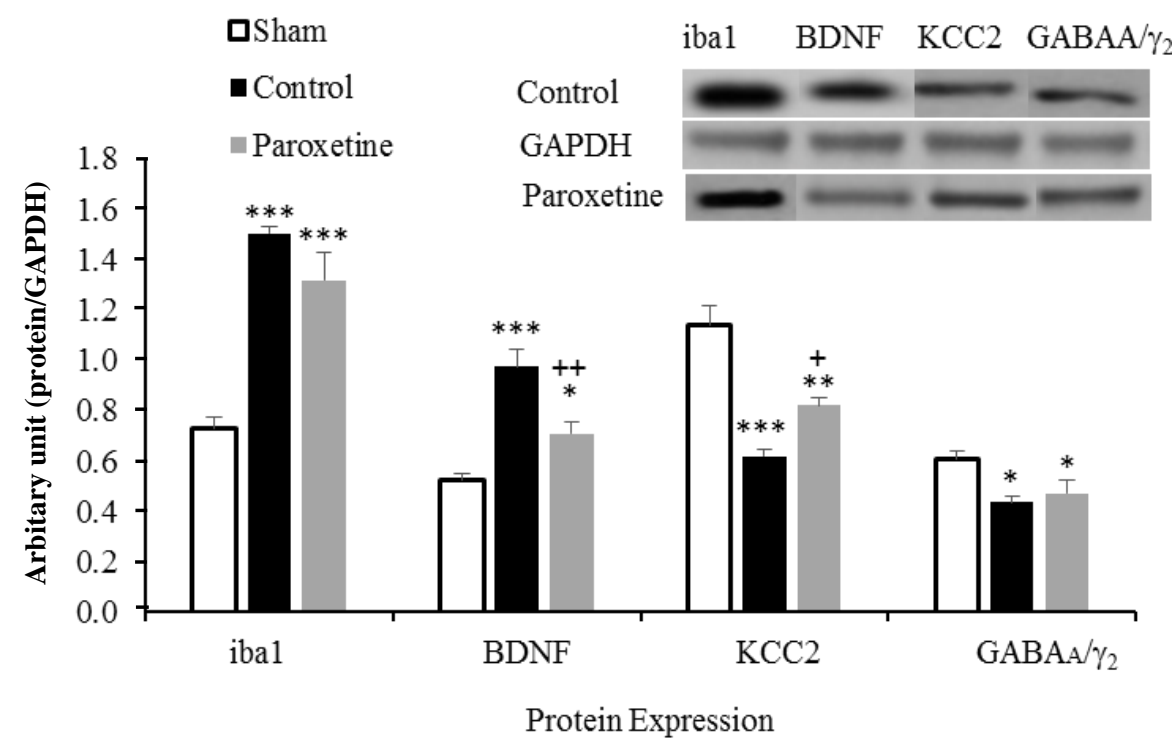

Fig. 4. Effect of paroxetine on of Iba1, BDNF, KCC2, and GABAA $/ \gamma_{2}$ protein levels administered after nerve injury. GAPDH was used as a loading control. Arbitrary unit: proteins optical density/GAPDH optical density. Data are expressed as means \pm SEM. ${ }^{*} p<$ $0.05,{ }^{* *} p<0.01$, and ${ }^{* * *} p<0.001$ indicate a statistically significant difference when compared to the sham group, and ${ }^{+} p<0.05,{ }^{++} p<$ 0.01 show significant difference compared to the control group.

of BDNF in neuropathic pain, this change in pain behavior is probably due to a shift in $B D N F$ expression, which is reduced by paroxetine when administered before and after nerve damage.

$\mathrm{KCC} 2$ is a transporter for potassium and chloride ions and contributes to the regulation of anion gradients on both sides of the membrane. This transporter plays a very important role in regulating GABAA receptor activity ${ }^{[43]}$. The post-synaptic activity of GABAA receptors in the adult nervous system leads to the opening of the chloride channel, neuronal hyperpolarization and as a result, its inhibitory activity ${ }^{[44,45]}$. The role of $\mathrm{KCC} 2$ has been proven in chlorine ion homeostasis in the spinal interneurons. KCC2 actively pumps the ion chloride to the outside of the neuronal cell to support conditions for the inhibitory activity of GABA receptors ${ }^{[46,47]}$. Moreover, the expression of $\mathrm{KCC} 2$ can contribute to the neuropathic pain induced by nerve injury ${ }^{[6,48,49]}$. In this study, paroxetine increased the expression of $K C C 2$ as compared to the control group when used before or after nerve injury. Further researches are needed to find out whether paroxetine directly affects the expression of this protein, or secondarily, by blocking the purinergic receptor that causes this change. The GABAA receptors existing at the end of the primary afferent neurons are responsible for their synaptic inhibition ${ }^{[50,51]}$. It has been proven that GABAA $/ \gamma_{2}$ expression decreases significantly in the DRG after the nerve injury ${ }^{[25]}$. However, after the nerve injury, the expression of $B D N F$ rises in DRG neurons, but the $\gamma_{2}$ subunit of GABAA receptors decreases concurrently ${ }^{[52]}$. As mentioned before, $\mathrm{KCC} 2$, as a key protein in regulating the equilibrium potential of anions, is crucial for the GABAA inhibitory effect ${ }^{[53]}$. Reduced expression of the $\mathrm{KCC} 2$ protein in dorsal horn of the spinal cord neurons leads to the elimination of the inhibitory function of GABAA receptor in case of chronic neuropathy ${ }^{[23,54]}$. However, considering what mentioned before, the inhibitory effect of GABAA receptor depends on two important factors: first, the expression of the receptor itself and its subunits, and the second, the post-synaptic activity of the membrane protein of KCC2. The findings of this study showed that only pre-injury injection of paroxetine resulted in the increased protein level of GABAA $/ \gamma_{2}$ receptors.

In conclusion, it seems that paroxetine with change in the expression of some important proteins involved in neuropathic pain (BDND, $\mathrm{KCC} 2$, and GABAA) attenuates neuropathic pain. This effect was observed either when paroxetine was administered before nerve injury or when it was injected after damage to the nerve.

\section{ACKNOWLEDGEMENTS}

This work has financially been supported by Shahid Beheshti University of Medical Sciences, Faculty of Medicine, Tehran, Iran. We are grateful to the Research Deputy of Shahid Beheshti University of 
Medical Sciences, Faculty of Medicine (Tehran, Iran) for their kind collaboration.

CONFLICT OF INTEREST. None declared.

\section{REFERENCES}

1. Backonja MM, Stacey B. Neuropathic pain symptoms relative to overall pain rating. The journal of pain 2004; 5(9): 491-497.

2. Hald A, Nedergaard S, Hansen RR, Ding M, Heegaard AM. Differential activation of spinal cord glial cells in murine models of neuropathic and cancer pain. European journal of pain 2009; 13(2): 138-145.

3. Hald A. Spinal astrogliosis in pain models: cause and effects. Cellular and molecular neurobiology 2009; 29(5): 609-619.

4. Kemler MA, de Vet HC, Barendse GA, van den Wildenberg FA, van Kleef M. Effect of spinal cord stimulation for chronic complex regional pain syndrome Type I: five-year final follow-up of patients in a randomized controlled trial. Journal of neurosergery 2008; 108(2): 292-298.

5. Bowery NG, Hudson AL, Price GW. GABAA and GABAB receptor site distribution in the rat central nervous system. Neuroscience 1987; 20(2): 365-383.

6. Price TJ, Cervero F, de Koninck Y. Role of cationchloride-cotransporters (CCC) in pain and hyperalgesia. Current topics in medicinal chemistry 2005; 5(6): 547555.

7. Vinay L, Jean-Xavier C. Plasticity of spinal cord locomotor networks and contribution of cation-chloride cotransporters. Brain research reviews 2008; 57(1): 103-110.

8. Cramer SW, Baggott C, Cain J, Tilghman J, Allcock B, Miranpuri G, Rajpal S, Sun D, Resnick D. The role of cation-dependent chloride transporters in neuropathic pain following spinal cord injury. Molecular pain 2008; 4(1): 36 .

9. Eaton MJ, Wolfe SQ, Martinez M, Hernandez M, Furst C, Huang J, Frydel BR, Gómez-Marín O. Subarachnoid transplant of a human neuronal cell line attenuates chronic allodynia and hyperalgesia after excitotoxic spinal cord injury in the rat. The journal of pain 2007; 8(1): 33-50.

10. Miletic G, Draganic P, Pankratz MT, Miletic V. Muscimol prevents long-lasting potentiation of dorsal horn field potentials in rats with chronic constriction injury exhibiting decreased levels of the GABA transporter GAT-1. Pain 2003; 105(1): 347-353.

11. Alvarez-Leefmans FJ, Leon-Olea M, Mendoza-Sotelo J, Alvarez FJ, Anton B, Garduno R. Immunolocalization of the $\mathrm{Na}^{+}-\mathrm{K}^{+} 2 \mathrm{Cl}^{-}$cotransporter in peripheral nervous tissue of vertebrates. Neuroscience 2001; 104(2): 569582 .

12. Misgeld U, Deisz RA, Dodt HU, Lux HD. The role of chloride transport in postsynaptic inhibition of hippocampal neurons. Science 1986; 232: 1413-1415.
13. Sung KW, Kirby M, McDonald MP, Lovinger DM, Delpire E. Abnormal GABAA receptor-mediated currents in dorsal root ganglion neurons isolated from $\mathrm{Na}-\mathrm{K}-2 \mathrm{Cl}$ cotransporter null mice. Journal neurosci 2000; 20(20): 7531-7538.

14. Miletic G, Miletic V. Loose ligation of the sciatic nerve is associated with TrkB receptor-dependent decreases in $\mathrm{KCC} 2$ protein levels in the ipsilateral spinal dorsal horn. Pain 2008; 137(3): 532-539.

15. DeLeo JA, Yezierski RP. The role of neuroinflammation and neuroimmune activation in persistent pain. Pain 2001; 90(1-2): 1-6.

16. Garrison $\mathrm{C}$, Dougherty $\mathrm{P}$, Kajander $\mathrm{K}$, Carlton $\mathrm{S}$. Staining of glial fibrillary acidic protein (GFAP) in lumbar spinal cord increases following a sciatic nerve constriction injury. Brain research 1991; 565(1): 1-7.

17. DeLeo JA, Colburn RW. Proinflammatory cytokines and glial cells: their role in neuropathic pain. Cytokines and pain 1999; 1999: 159-181.

18. Zhuang ZY, Kawasaki Y, Tan PH, Wen YR, Huang J, Ji R-R. Role of the CX3CR1/p38 MAPK pathway in spinal microglia for the development of neuropathic pain following nerve injury-induced cleavage of fractalkine. Brain, behavior, and immunity 2007; 21(5): 642-651.

19. Trang T, Beggs S, Wan X, Salter MW. P2X4-receptormediated synthesis and release of brain-derived neurotrophic factor in microglia is dependent on calcium and p38-mitogen-activated protein kinase activation. Journal neurosci 2009; 29(11): 3518-3528.

20. Merighi A, Salio C, Ghirri A, Lossi L, Ferrini F, Betelli C, Bardoni R. BDNF as a pain modulator. Progress in neurobiolgy 2008; 85(3): 297-317

21. Obata K, Noguchi K. BDNF in sensory neurons and chronic pain. Journal of neuroscience research 2006; 55(1): 1-10.

22. Pezet S, McMahon SB. Neurotrophins: mediators and modulators of pain. Annual review of neuroscience 2006; 29: 507-538.

23. Coull JA, Beggs S, Boudreau D, Boivin D, Tsuda M, Inoue K, Gravel C, Salter MW, De Koninck Y. BDNF from microglia causes the shift in neuronal anion gradient underlying neuropathic pain. Nature 2005; 438(7070): 1017-1021.

24. Rivera C, Li H, Thomas-Crusells J, Lahtinen H, Viitanen T, Nanobashvili A, Kokaia Z, Airaksinen MS, Voipio J, Kaila K.Saarma M. BDNF-induced TrkB activation down-regulates the $\mathrm{K}^{+}-\mathrm{Cl}^{-}$cotransporter $\mathrm{KCC} 2$ and impairs neuronal $\mathrm{Cl}-$ extrusion. Journal cell biologyl 2002; 159(5): 747-752.

25. Fukuoka T, Tokunaga A, Kondo E, Miki K, Tachibana $\mathrm{T}$, Noguchi K. Change in mRNAs for neuropeptides and the $\mathrm{GABA}<\mathrm{sub}>\mathrm{A}</ \mathrm{sub}>$ receptor in dorsal root ganglion neurons in a rat experimental neuropathic pain model. Pain 1998; 78(1): 13-26.

26. Inoue $\mathrm{K}$, Tsuda M. Purinergic systems, neuropathic pain and the role of microglia. Experimental neurology 2012; 234(2): 293-301.

27. Wang W, Gu J, Li YQ, Tao YX. Are voltage-gated sodium channels on the dorsal root ganglion involved in 
the development of neuropathic pain. Molecular pain 2011; 7: 16.

28. Toulme E, Garcia A, Samways D, Egan TM, Carson MJ, Khakh BS. P2X4 receptors in activated C8-B4 cells of cerebellar microglial origin. The journal of general physiology 2010; 135(4)333-353.

29. Wall P, Devor M, Inbal R, Scadding J, Schonfeld D, Seltzer Z, Tomkiewicz M. Autotomy following peripheral nerve lesions: experimental anesthesia dolorosa. Pain 1979; 7(2): 103-113.

30. Ji RR, Suter MR. p38 MAPK, microglial signaling, and neuropathic pain. Molecular Pain 2007; 3: 33.

31. Inoue K, Tsuda M. Microglia and neuropathic pain. Glia 2009; 57(14): 1469-1479.

32. Imai Y, Ibata I, Ito D, Ohsawa K, Kohsaka S. A novel gene ibal in the major histocompatibility complex class III region encoding an EF hand protein expressed in a monocytic lineage. Biochemical and biophysical research communications 1996; 224(3): 855-862.

33. Ito D, Imai Y, Ohsawa K, Nakajima K, Fukuuchi Y, Kohsaka S. Microglia-specific localisation of a novel calcium binding protein, Iba1. Molecular brain research 1998; 57(1): 1-9.

34. Ohsawa K, Neo M, Matsuoka H, Akiyama H, Ito H, Kohno H, Nakamura T. The expression of bone matrix protein mRNAs around beta-TCP particles implanted into bone. Journal of biomedical materials research 2000; 52(3): 460-466.

35. Romero-Sandoval A, Chai N, Nutile-McMenemy N, DeLeo JA. A comparison of spinal Ibal and GFAP expression in rodent models of acute and chronic pain. Brain research 2008; 1219: 116-126.

36. Xiaodi Y, Shuangqiong Z, Qianbo C, Chengwen C, Hongbin Y. P2X4 receptor and brain-derived neurotrophic factor in neuropathic pain. Journal of medical colleges of PLA 2010; 25(5): 275-284.

37. Inoue K, Koizumi S, Tsuda M, Shigemoto-Mogami Y. Signaling of ATP receptors in glia-neuron interaction and pain. Life science 2003; 74(2-3): 189-197.

38. Trang T, Salter MW. P2X4 purinoceptor signaling in chronic pain. Purinergic signalling 2012; 8(3): 621-628.

39. North RA. Molecular physiology of P2X receptors. Physiological reviews 2002; 82(4): 1013-1067.

40. Geng SJ, Liao F-F, Dang WH, Ding X, Liu XD, Cai J, Han JS, Wan Y, Xing G-G. Contribution of the spinal cord BDNF to the development of neuropathic pain by activation of the NR2B-containing NMDA receptors in rats with spinal nerve ligation. Experimental neurology 2010; 222(2): 256-266.

41. Hayashida KI, Clayton BA, Johnson JE, Eisenach JC. Brain derived nerve growth factor induces spinal noradrenergic fiber sprouting and enhances clonidine analgesia following nerve injury in rats. Pain 2008; 136(3): 348-355 .
42. Zarei M, Sabetkasaei M, Zanjani TM. Paroxetine attenuates the development and existing pain in a rat model of neurophatic pain. Iranian biomedical journal 2014; 18(2): 94 -100.

43. Lu Y, Zheng J, Xiong L, Zimmermann M, Yang J. Spinal cord injury-induced attenuation of GABAergic inhibition in spinal dorsal horn circuits is associated with down regulation of the chloride transporter $\mathrm{KCC} 2$ in rat. The journal of physiology 2008; 586(23): 57015715 .

44. Kaila K. Ionic basis of GABA sub $\mathrm{A} / \mathrm{sub}$ receptor channel function in the nervous system. Progress in neurobiology 1994; 42(4): 489-537.

45. Lu Y, Perl ER. A specific inhibitory pathway between substantia gelatinosa neurons receiving direct $\mathrm{C}$-fiber input. The journal of neuroscience 2003; 23(25): 87528758.

46. Delpire E. Cation-chloride cotransporters in neuronal communication. Physiology 2000; 15(6): 309-312.

47. Payne JA, Rivera C, Voipio J, Kaila K. Cationchloride co-transporters in neuronal communication, development and trauma. Trends neuroscience 2003; 26(4): 199-206.

48. Coull JA, Beggs S, Boudreau D, Boivin D, Tsuda M, Inoue K, Gravel C, Salter MW, DeHoninck Y. BDNF from microglia causes the shift in neuronal anion gradient underlying neuropathic pain. Nature 2005; 438(7070): 1017-1021.

49. De Koninck Y. Altered chloride homeostasis in neurological disorders: a new target. Current opinion pharmacol 2007; 7(1): 93-99.

50. Rudomin P. Presynaptic inhibition of muscle spindle and tendon organ afferents in the mammalian spinal cord. Trends neuroscience 1990; 13(12): 499-505.

51. Sluka KA, Willis WD, Westlund KN. Inflammationinduced release of excitatory amino acids is prevented by spinal administration of a GABAA but not by a GABAB receptor antagonist in rats. Journal of pharmacology and experimental therapeutics 1994; 271(1): 76-82.

52. Obata K, Yamanaka H, Fukuoka T, Yi D, Tokunaga A, Hashimoto N, Yoshikawa H, Noguchi K. Contribution of injured and uninjured dorsal root ganglion neurons to pain behavior and the changes in gene expression following chronic constriction injury of the sciatic nerve in rats. Pain 2003; 101(1-2): 65-77.

53. Price TJ, Cervero F, Gold MS, Hammond DL, Prescott SA. Chloride regulation in the pain pathway. Brain research reviews 2009; 60(1): 149-170.

54. Janssen S, Truin M, Van Kleef M, Joosten E. Differential GABAergic disinhibition during the development of painful peripheral neuropathy. Neuroscience 2011; 184: 183-194. 